\title{
E-governance applications and usage patterns in developing countries
}

\author{
Hasanain Mohammed Manji Al-Rzoky ${ }^{1}$, Shuruq Khalid Abdul Redha Al Mahdi², Payman Hussein \\ Hussan Al-Samariy ${ }^{3}$ \\ ${ }^{1,2}$ Directorate Education of Babylon, Ministry of Education, Iraq \\ ${ }^{3}$ Babylon Technical Institute, Al-Furat Al-Awsat Technical University, Iraq
}

\section{Article Info}

Received, 2019

Keyword:
Developing Countries and
Online Applications
E-Governance
Online Governance

Corresponding Author:

Hasanain Mohammed Manji Al-Rzoky ${ }^{1}$

Directorate Education of Babylon,

Ministry of Education,Iraq

Email: Hasanain.comp86@gmail.com

\begin{abstract}
E-Governance integrates the use and implementation of technology based suites and modules for the usage in the public domain so that the common persons can be able to use this segment without harassment in public offices. The approach of e-governance associates the online services so that the real time analytics and the implementation can be done to the public services without any delay and with higher degree of accuracy. The use of egovernance is quite prominent in assorted streams whereby the citizen identification and the government services are required to be associated so that the higher performance and cumulative recital is there. The paradigm and implementation perspectives of e-governance are required in the citizens based services for governance and services towards the access to government schemes and thereby this manuscript is having the key focus in this segment for the usage patterns of e-governance in the assorted aspects with specific scenarios of developing countries. In this research work, the adoption and integration of e-governance is associated as the key point towards the smart applications in the smart environment. For the development and growth of any country, there is need to associate the technology based products and services. These are the key points in the smart environment with the e-governance in any region. This work is pointing out these perspectives of e-governance and online services.
\end{abstract}

\section{Introduction}

E-Governance refers to the usage of Information and Communication (ICT) based technologies for the integration of government with social services for the citizens [1,2]. The objectives and goals of e-governance are to provide the higher accuracy aware services to the citizens so that the overall social and economic elevation can be done with the cumulative performance with the availabilities in the escalated key points $[3,4,5,6,7,8]$. The key areas and segments of e-governance [6,9] includes: i. Government-To-Citizen (G2C), ii. Government-To-Government (G2G), iii. Government-To-Employees (G2E), iv. Government-To-Business (G2B). These are the prime delivery channels to the citizens and general implementations. The paradigm of e- 
governance is having the assorted aspects with the construe and citadel towards the enormous points $[8,10,11,12]$ :

- Internal Organization

- Business Aspects

- Government Services

- Organizational Aspects

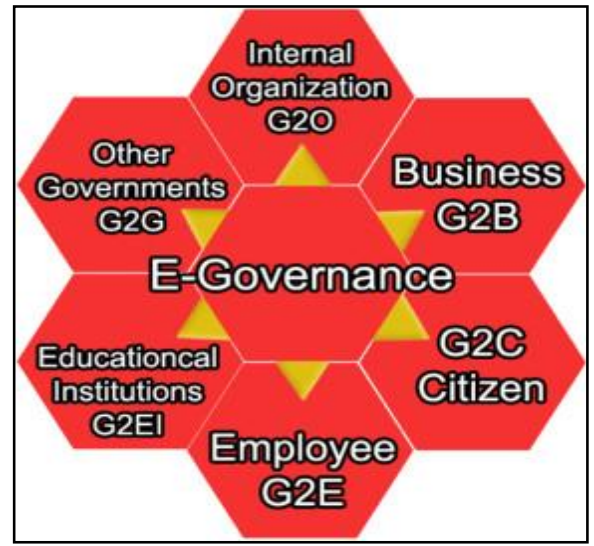

Figure 1. Key Aspects of E-Governance[13]

"Fig. 1" is presenting the assorted key points of e-governance. The government agencies strive to implement the services of e-governance so that the enormous features of governance can be integrated [14,15]. EGovernance incorporates the utilization and execution of innovation based suites and modules for the use in the open space so the regular people can probably utilize this fragment without badgering in open workplaces. The methodology of e-governance relates the online administrations so the constant investigation and the usage should be possible to the open administrations immediately and with higher level of exactness. The utilization of e-governance is very noticeable in arranged streams whereby the native recognizable proof and the taxpayer supported organizations are required to be related with the goal that the higher presentation and total presentation $[16,17]$.

The worldview and execution points of view of e-governance are required in the resident based administrations for governance and administrations towards the entrance to government plans and along these lines this original copy is having the key concentration in this fragment for the utilization examples of egovernance in the different perspectives with explicit situations of creating nations $[18,19]$.

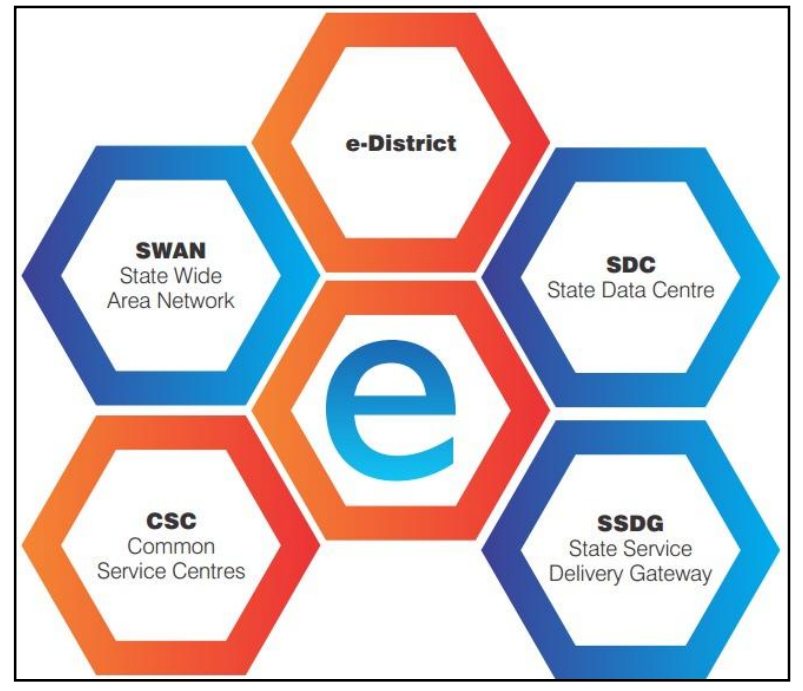

Figure 2. Implementation Patterns with E-Governance[20] 
"Fig. 2" is depicting the use case patterns and implementation aspects of e-governance so that the all time availabilities can be done with the integration of e-governance.

\subsection{Advantages}

- Speed

- Cost Optimization

- Transparency

- Accountability

\subsection{Limitations}

- Loss in Interpersonal Communications

- Higher Cost

- Technical Aspects

- Illiteracy

- Cybercrimes

\section{Usage of E-Governance with Blockchain Technologies for Security}

E-Governance is now days quite prominent with the blockchain integration so that the higher security can be provided without any scope of cracking. Blockchain is the state-of-the-art technology that is always associated with security and higher degree of privacy in assorted applications [21,22,23]. Now days, blockchain technology is not limited to the crypto-currencies rather it is under implementation for various social and corporate segments [24,25]. These segments include e-governance, social networking, e-commerce, transportation, logistics, professional communications and many others[7,22,26,27].

Blockchain refers to the high performance and security aware technology in which a digital ledger is maintained. The digital ledger is quite transparent and there is no scope of any manipulations in the records by the intermediates or any administrator. The records of all the transactions are logged in the blockchain ledger and the operations are committed final with different protocols and algorithms which cannot be hacked by the third party intrusions. In blockchain network, there exists the blocks of different data elements and records $[13,28,29,30]$.

Each block participates in the blockchain network and it is immutable. The term immutable here refers that it is secured and non-breakable. Hence it forms the blockchain of secured chain of blocks without any probabilities of intentional or accidental tampering or leakage in the data. The first block in the chain of network is known as the Genesis Block from where the blockchain initiates the transactions. With the increase by inserting different blocks with encryption of every block with previous block, it becomes secured and therefore difficult to crack the previous states because of so many encryptions [22,31,32].

In Blockchain Programming, the Proof-of-Work (PoW) is one of the very important algorithms. It is used to confirm and validate the transactions so that the new blocks are added in the blockchain. It is referred as the key consensus algorithm for the verifications and authenticity of the transactions. In blockchain network, different miners participate for the validation and completing the transactions. For the successful validations, the miners are rewarded with the digital crypto-currencies as their remuneration $[22,32]$.

This process also avoids the double spending problem so that the digital currency or transaction is implemented in secured way. For example, if A transmit a file or digital currency to B. In this case, that specific file or currency values in the records of A must be deleted and then should be reflected in the records 
of B. Traditionally, it is done by the Bank as intermediate. In case of blockchain network, it is implemented without any intermediate and it is validated automatically using specialized algorithms. If there are instances of non deleting the transaction from sender, it will de-evaluate the currency despite of the type of currency [33,34].

In current scenarios, the governments as well as corporate organizations are striving towards the implementation of blockchain technology for secured application. For these integrations, there is need to associate the secured algorithms of Proof of Work (PoW) so that the privacy and integrity of implementations will be there. The research scholars and forensic scientists can make use of blockchain technologies so that the exact and accurate prediction of specific identities shall be there which can be used for the criminal forensic as well as the law enforcement scenarios. In this regard, we have bolster the issue of encryption as a development platform that can help national people with weak Internet access such as Iraq [22]. Following are some of the examples of Blockchain Implementations:

\begin{tabular}{|c|c|c|c|}
\hline $\begin{array}{ll}\text { Entertainment } \\
\text { - } \\
\text { - } \\
\text { - } \text { BickCity } \\
\text { - } \quad \text { Spotify } \\
\text { - Gund } \\
\text { - } \quad \text { Veredictum }\end{array}$ & $\begin{array}{ll}\text { Social Networks } \\
\text { - } & \text { Matchpool } \\
\text { - } & \text { Minds } \\
\text { - } & \text { MeWe } \\
\text { - } & \text { Steepshot } \\
\text { - } & \text { DTube } \\
\text { - } & \text { Mastodon } \\
\text { - } & \text { Sola }\end{array}$ & $\begin{array}{ll}\text { Cryptocurrency } \\
\text { - } & \text { Bitcoin } \\
\text { - } & \text { Litecoin } \\
\text { - } & \text { Namecoin } \\
\text { - } & \text { Dogecoin } \\
\text { - } & \text { Primecoin } \\
\text { - } & \text { Nxt } \\
\text { - } & \text { Ripple } \\
\text { - } & \text { Ethereum }\end{array}$ & $\begin{array}{ll}\text { Retail } \\
\text { - } \quad \text { Warranteer } \\
\text { - } \text { Blockpoint } \\
\text { - } \text { Loyyal } \\
\text { - } \text { Fluz Fluz } \\
\text { - } \text { Shopin } \\
\text { - Spl.yt } \\
\text { - Opskins } \\
\text { - Ecoinmerce.io } \\
\text { - Every.Shop } \\
\text { - } \text { Portion } \\
\text { - } \text { Buying.com }\end{array}$ \\
\hline
\end{tabular}

\section{Challenges in E-Governance}

- Infrastructure

- Law and Public Strategies

- Law Enforcement

- Trust

- Physical Disability

- Digital Divide

- Privacy

- Integrity

- Eradicate the roots of Corruption

- Education and Marketing

- Records Management

- Workforce Management

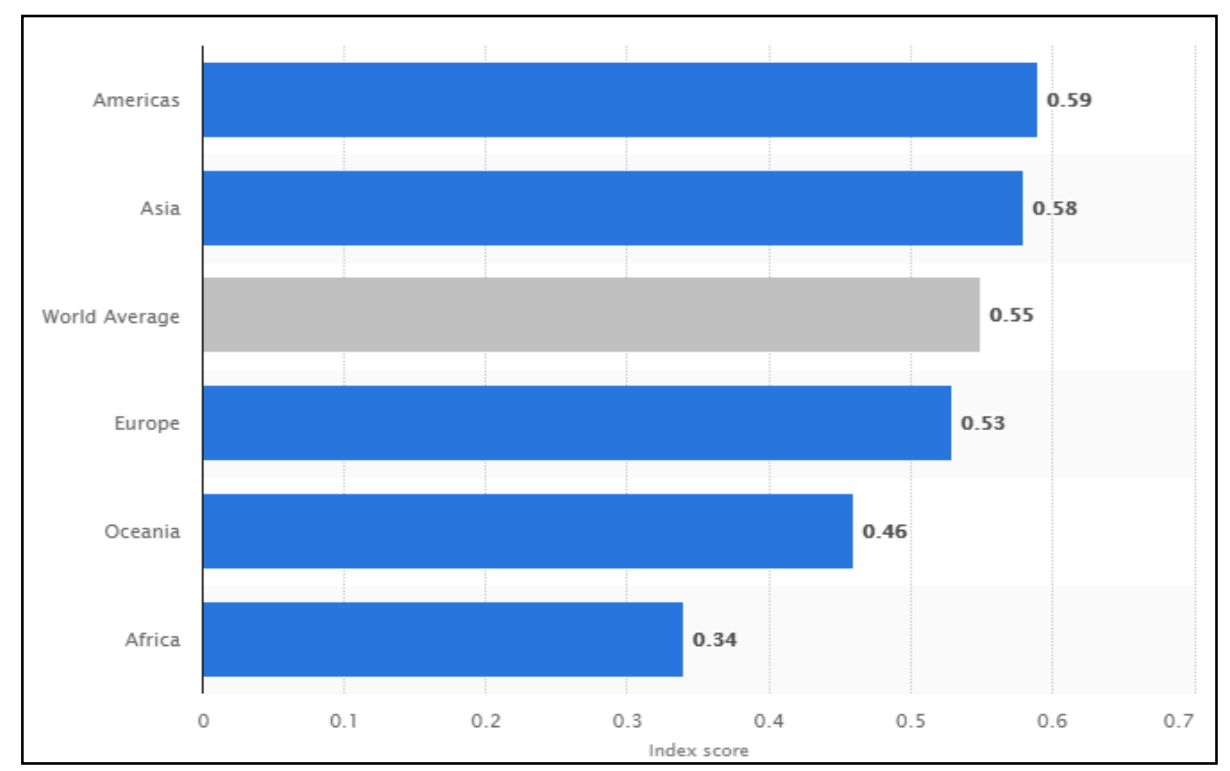

Figure 3. E-Government Development Index (EGDI) of Global Regions in 2018[35] 
"Fig. 3" is showing the EGDI as the index with the global points of implementation in year 2018 and showing that there is huge elevation in the integration for the citizen services.

\section{Usage Patterns of E-Governance in Developing Countries}

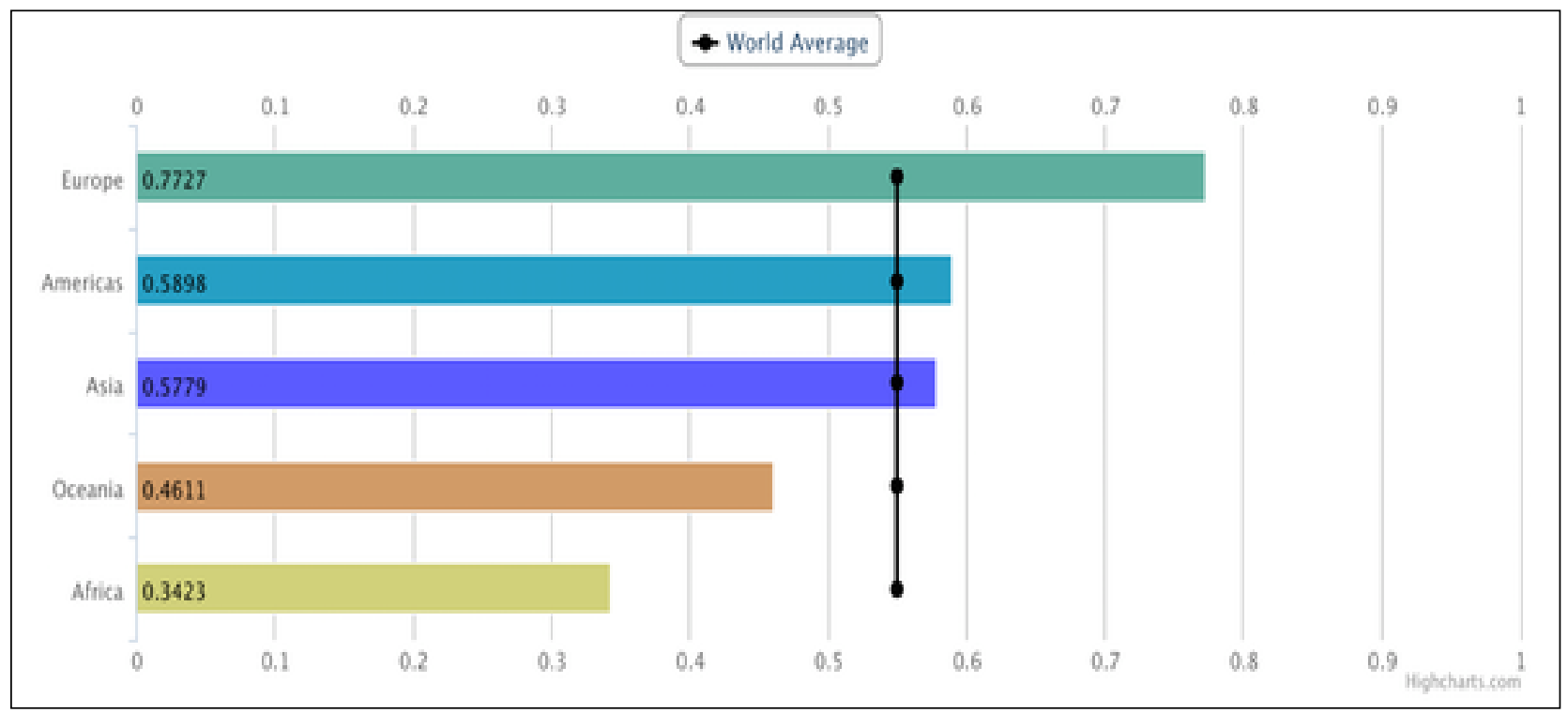

Figure 4. World Wide Average[35]

Be that as it may, developing and actualizing e-government is troublesome and take-up among natives can be slow. Whereas, Denmark is the main positioned nation in online service conveyance in 2018 where seen $89 \%$ of its residents utilizing e-services. On the contrary, numerous different nations are wrestling to advancement e-government for instance Egypt e-services take-up is only $2 \%$.

Table 1 is showing the e-governance survey report of year 2018 with the key perspectives so that the cumulative performance can be depicted to the higher degree of performance.

Table 1: E-Government Survey Report 2018[36,37]

\begin{tabular}{cc}
\hline $\begin{array}{c}\text { E-Government Development Index - Top 10 Countries } \\
\text { Country }\end{array}$ & 0.8999 \\
\hline United Kingdom & 0.9053 \\
Australia & 0.9150 \\
Denmark & 0.8882 \\
Sweden & 0.8815 \\
Finland & 0.9010 \\
Republic of Korea & 0.8790 \\
France & 0.8806 \\
New Zealand & 0.8812 \\
Singapore & 0.8783 \\
Japan &
\end{tabular}




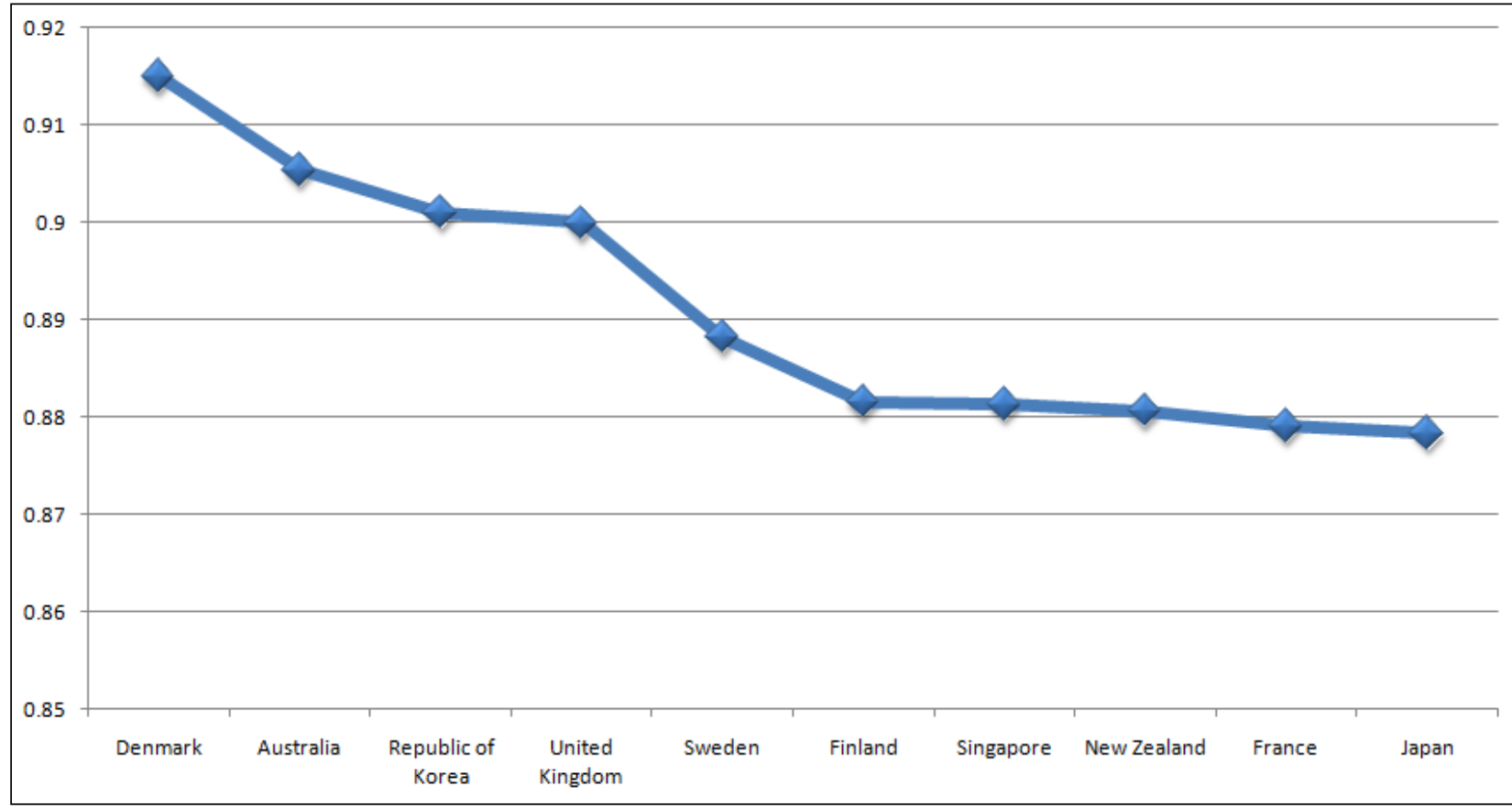

Figure 5. E-Governance Survey Report[36,37]

Table 2 is having the depiction of the e-participation of the countries with the key integration of e-governance for the upliftment of the government services and the schemes [38,39,40,41].

Table 2. E-Participation Index with Key 11 Countries[36,37]

\begin{tabular}{cc}
\hline Country & Index \\
\hline Republic of Korea & 1 \\
Australia & 0.9831 \\
Netherlands & 0.9888 \\
Finland & 1 \\
Denmark & 1 \\
Spain & 0.9831 \\
Japan & 0.9831 \\
United States of America & 0.9831 \\
Norway & 0.9775 \\
New Zealand & 0.9831 \\
United Kingdom & 0.9831 \\
\hline
\end{tabular}




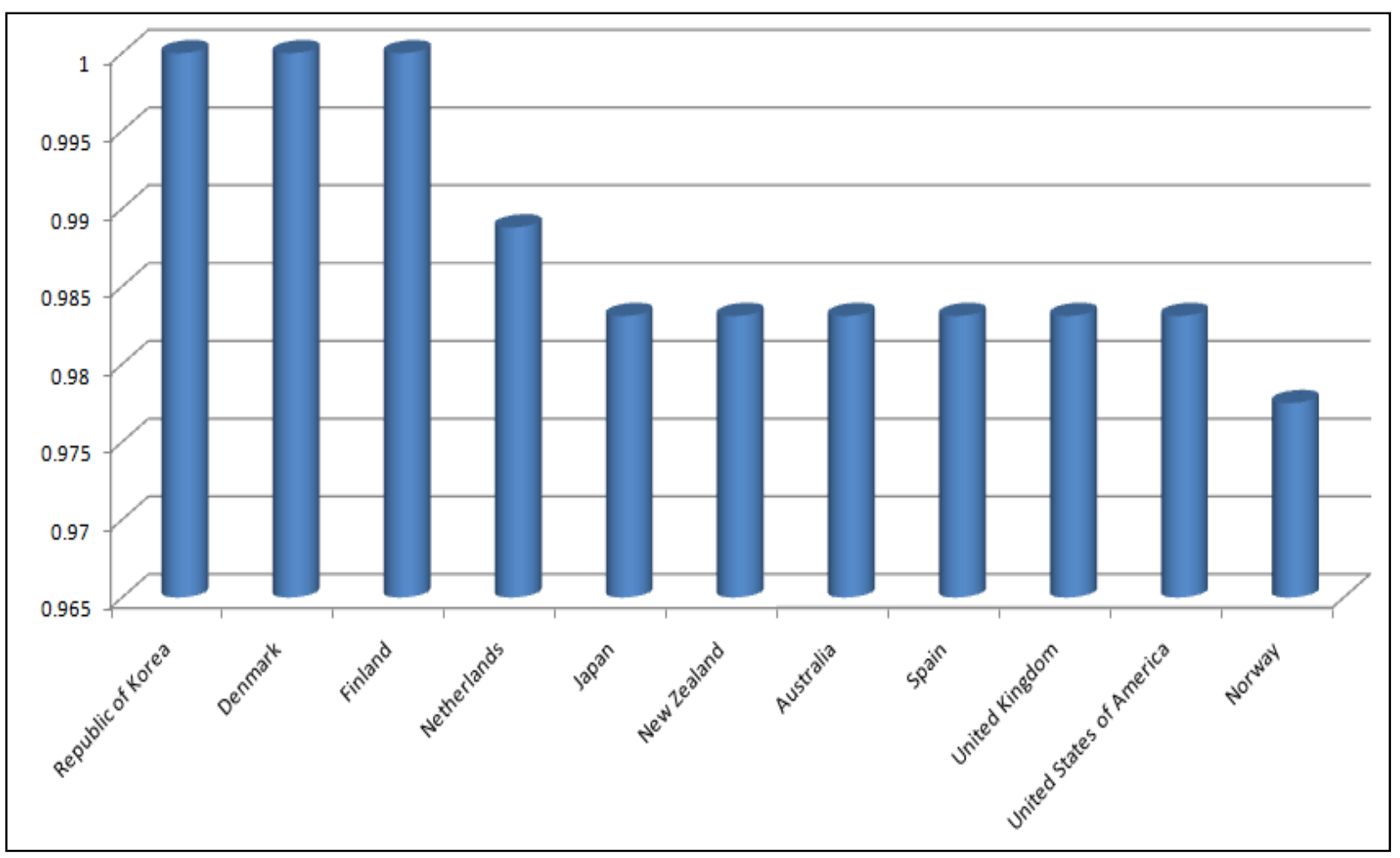

Figure 6. E-Governance Participation Report[36]

\section{E-Governance in Iraq}

Iraq is one of the countries moving ahead towards the integration and implementation of technology based suites and the products for the government and the social services.

Table 3 is presenting the e-government development index that is specific to the use case patterns of Iraq and thereby to have the key points of government services in the citizen domains.

Table 3. E-government development index[36,37]

\begin{tabular}{cccc}
\hline Country & Globally Rank & Arab Rank & Index Value \\
\hline United Arab Emirates & 28 & 1 & 0.7344 \\
Bahrain & 36 & 2 & 0.6946 \\
Qatar & 48 & 3 & 0.6405 \\
Kuwait & 63 & 4 & 0.5960 \\
Oman & 64 & 5 & 0.5944 \\
Lebanon & 87 & 6 & 0.5139 \\
Jordan & 98 & 7 & 0.4884 \\
Tunisia & 103 & 8 & 0.4833 \\
Egypt & 107 & 9 & 0.4611 \\
Morocco & 120 & 10 & 0.4209 \\
Syrian Arab Republic & 128 & 11 & 0.3705 \\
Algeria & 132 & 12 & 0.3608 \\
Iraq & $\mathbf{1 3 7}$ & $\mathbf{1 3}$ & $\mathbf{0 . 3 4 0 9}$ \\
Sudan & 165 & 14 & 0.2610 \\
Yemen & 167 & 15 & 0.2472 \\
\hline
\end{tabular}


The depiction of tabular data of Iraq is showing that there is huge elevation in the practices of e-governance in Iraq and numbers of projects are running with the support of government agencies.

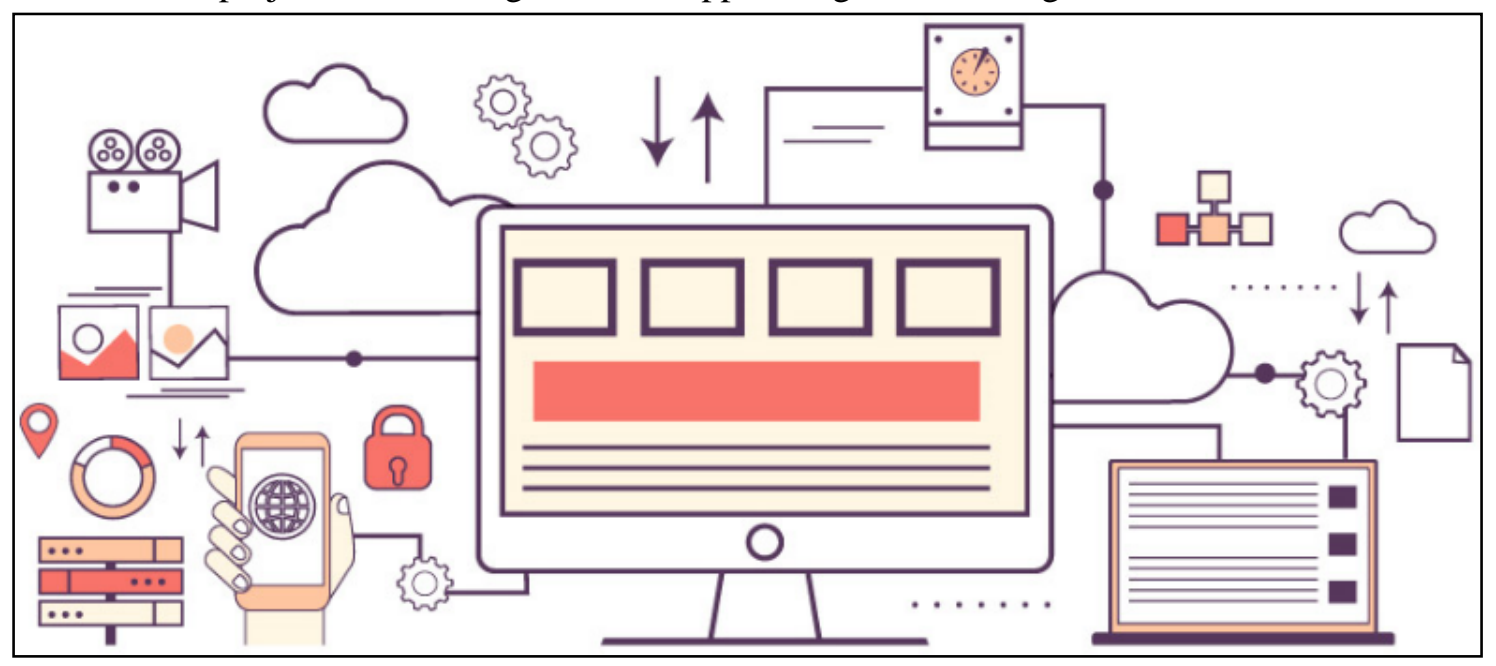

Figure 7. E-Governance Points

"Fig. 7" is having the view of government services which can be accessed using e-governance despite of any region. These services and clients include mobile, tabs, laptops and many other devices.

\section{Conclusion}

E-Governance is now days under adoption and implementation by many countries so that the citizen services can be escalated with higher performance without any scope of corruption. The domain of e-governance is not limited to specific domains rather it is extended towards the services including E-Benefits, E-Payroll, EIdentification and many others. E-administration incorporates the utilization and usage of innovation based suites and modules for use in the open area so common individuals can utilize this section without provocation in open workplaces. The e-government approach partners online administrations so continuous investigation and usage can be performed immediately and with more noteworthy exactness in open administrations. The utilization of electronic administration is very significant in an assortment of streams where it is important to relate the distinguishing proof of residents and taxpayer supported organizations so that there is better execution and an aggregate presentation. The worldview and points of view for the usage of electronic administration are required in citizenship-based administrations for administration and administrations for getting to government plans and, consequently, this original copy has the principle objective in this section. for models of utilization of electronic administration in different angles. with explicit situations in creating nations. In this exploration work, the selection and incorporation of electronic government is related as the key point towards savvy applications in a shrewd domain. For the advancement and development of any nation, it is important to consolidate innovation based items and administrations. These are the key focuses in the savvy condition with electronic government in any district. This work demonstrates these prospects for egovernment and online administrations. The manuscript is presenting the usage patterns and implementation perspectives of e-governance in assorted aspects for the multiple dimensions.

\section{References}

[1] S. Bose and M. R. Rashel, "Implementing e-governance using oecd model (modified) and gartner model (modified) upon agriculture of Bangladesh," in 2007 10th international conference on computer and information technology, 2007, pp. 1-5.

[2] G. D. Garson, Public information technology and e-governance: Managing the virtual state. Jones \& Bartlett Learning, 2006. 
[3] P. Rossel and M. Finger, "Conceptualizing e-governance," in Proceedings of the 1st international conference on Theory and practice of electronic governance, 2007, pp. 399-407.

[4] W. J. Miller and J. D. Walling, "Government in the twenty-first century: New Avenues of Study. Taking Sides.” New York: McGraw Hill, 2013.

[5] W. Xia and G. Lee, "Grasping the complexity of IS development projects," Commun. ACM, vol. 47, no. 5, pp. 68-74, 2004.

[6] Noelle Knell, "2012 Best of the Web Award Winners Announced,” 2012.

[7] S. Bethu, "Data Science: Identifying influencers in Social Networks," Periodicals of Engineering and Natural Sciences, vol. 6, no. 1, pp. 215-228, 2018.

[8] V. Honcharenko, A. Panteleimonenko, A. Pozhar, and V. Stetsenko, "Cooperatives in IT sector: theoretical and practical aspects," Periodicals of Engineering and Natural Sciences, vol. 7, no. 2, pp. 597-607, 2019.

[9] B. Lufkin, "Could Estonia be the First 'Digital'Country," Retrieved from BBC Futur. http//www. bbc. com/future/story/20171019-could-estonia-be-the-first-digital-country, 2017.

[10] J. D. White, Managing information in the public sector. Routledge, 2015.

[11] J. C. Bertot, P. T. Jaeger, and C. R. McClure, "Citizen-centered e-government services: benefits, costs, and research needs," in Proceedings of the 2008 international conference on Digital government research, 2008, pp. 137-142.

[12] Z. Fang, "E-government in Digital Era: Concept, Development, and Practice," Int. J. Comput. Internet Manag., vol. 10, no. 2, pp. 1-22, 2002.

[13] S. C. Palvia and S. Sharma, "E-Government and E-Governance: Definitions/Domain Framework and Status around the World (Foundations of E-government, A. Agarwal and VV Ramana)," Hyderabad, India IECG, 2007.

[14] L. Carter and F. Belanger, "Citizen adoption of electronic government initiatives," in 37th Annual Hawaii International Conference on System Sciences, 2004. Proceedings of the, 2004, pp. 10-pp.

[15] S. S. Dawes, "The evolution and continuing challenges of e-governance," Public Adm. Rev., vol. 68, pp. S86-S102, 2008.

[16] V. Ndou, "E-government for developing countries: opportunities and challenges," Electron. J. Inf. Syst. Dev. Ctries., vol. 18, pp. 1-24, 2004.

[17] R. Nemat, "Taking a look at different types of e-commerce," World Appl. Program., vol. 1, no. 2, pp. 100-104, 2011.

[18] K. A. Fakeeh, “The E-Governance (E-GOV) Information Management Models,” 2016.

[19] E. L. Chao, "US department of labor e-government strategic plan: Transforming into a digital department," Washington, DC Dep. Labor, 2003.

[20] P. Malik, P. Dhillon, and P. Verma, "Challenges and future prospects for E-governance in india," Int. J. Sci. Eng. Technol. Res., vol. 3, no. 7, pp. 1964-1972, 2014.

[21] A. K. Oo, T. Lwin, K. K. Oo, P. Aung, and T. Z. Ohn, "Framework development for evaluating egovernment portals in Myanmar using analytic hierarchy process," in 2012 Second International Conference on Digital Information and Communication Technology and it's Applications (DICTAP), 2012, pp. 166-171.

[22] H. A. Mutar and M. S. AL-Huseiny, "Implementation of national cryptocurrency using ethereum development platform," Periodicals of Engineering and Natural Sciences, vol. 7, no. 3, pp. 1021-1029, 2019. 
[23] H. AlShihi, "Critical Factors in the Adoption and Diffusion of E-government Initiatives in Oman." Victoria University, 2006.

[24] S. Marche and J. D. McNiven, "E-government and e-governance: the future isn't what it used to be," Can. J. Adm. Sci. Can. des Sci. l'Administration, vol. 20, no. 1, pp. 74-86, 2003.

[25] M. J. Moon, "The evolution of e-government among municipalities: rhetoric or reality?," Public Adm. Rev., vol. 62, no. 4, pp. 424-433, 2002.

[26] T. Banerjee, M. Mishra, N. C. Debnath, and P. Choudhury, "Implementing E-Commerce model for Agricultural Produce: A Research Roadmap," Periodicals of Engineering and Natural Sciences, vol. 7, no. 1, pp. 302-310, 2019.

[27] S. Saxena and S. Kumar Sharma, "Integrating Big Data in 'e-Oman': opportunities and challenges," info, vol. 18, no. 5, pp. 79-97, 2016.

[28] D. Arwati and D. V. Latif, "Factors Inhibiting Public Participation in corruption Prevention through EGovernment Application in Indonesia.," Glob. Bus. Manag. Res., vol. 11, no. 1, 2019.

[29] M. M. Brown, "Electronic government," Encycl. Public Adm. Public Policy, Marcel Dekker, pp. 427432, 2003.

[30] H. M. Treasury, "Putting the frontline first: smarter government," Cm, vol. 7753, pp. 22-25, 2009.

[31] W. Nasri, “Citizens' E-Government Services Adoption: An Extension of Unified Theory of Acceptance and Use of Technology Model," Int. J. Public Adm. Digit. Age, vol. 1, no. 2, pp. 80-96, 2014.

[32] S. H. Bakry, "Development of e-government: a STOPE view," Int. J. Netw. Manag., vol. 14, no. 5, pp. 339-350, 2004.

[33] D. Gilbert, P. Balestrini, and D. Littleboy, "Barriers and benefits in the adoption of e-government," Int. J. Public Sect. Manag., vol. 17, no. 4, pp. 286-301, 2004.

[34] S. Al-Sehali, "The factors that affect the implementation of enterprise resource planning (ERP) in the international Arab Gulf states and United States companies with special emphasis on SAP software," 2000 .

[35] Statista, "Statista - The Statistics Portal for Market Data, Market Research and Market Studies," 2018. [Online]. Available: https://www.statista.com/. [Accessed: 29-Sep-2019].

[36] United Nations, "United Nations E-Government Survey 2018: Gearing E-Government to support transformation towards sustainable and resilient societies," New York, NY United Nations, 2018.

[37] United Nations, "Dataset EGOVKB-Data center," 2018. [Online]. Available: https://publicadministration.un.org/egovkb/Data-Center. [Accessed: 29-Sep-2019].

[38] R. D. Atkinson and D. Castro, "Digital quality of life: Understanding the personal and social benefits of the information technology revolution," Available SSRN 1278185, 2008.

[39] S. A. Becker, "Bridging literacy, language, and cultural divides to promote universal usability of egovernment websites," J. Electron. Commer. Organ., vol. 1, pp. i-iv, 2003.

[40] J. Lyman, "AT\&T Sued for Role in Aiding US Government Surveillance," TechNewsWorld, available online from http//www. technewsworld. com/story/48629. html, 2006.

[41] R. Singel, "Analysis: new law gives government six months to turn internet and phone systems into permanent spying architecture," Wired. Retrieved, pp. 2-28, 2008. 